\title{
INDUCTION OF BLASTOCYST IMPLANTATION IN MICE BY CYCLIC AMP
}

\author{
P. V. HOLMES* AND S. BERGSTRÖM $\dagger$ \\ Department of Human Anatomy, Biomedical Centre, \\ Uppsala, Sweden
}

(Received 26th September 1974)

\begin{abstract}
Summary. Oestrogen administration to female mice with 'delayed' implantation induces changes in the uterus and blastocysts followed by implantation and normal gestation. The second messenger for oestrogen, adenosine $3^{\prime}: 5^{\prime}$-cyclic monophosphate (cAMP), was instilled into the uterine lumen of females with 'delayed implanting' blastocysts to determine whether it also is able to induce implantation. Implantation of the blastocysts was induced by cAMP but the pregnancies were not maintained to term. These results are discussed with respect to the changes in blastocysts induced by cAMP and with respect to the reported contraceptive effects of cAMP in normal mice.
\end{abstract}

It has been established that the administration of oestrogen induces implantation of 'delayed' blastocysts in ovariectomized pregnant mice given progesterone and in lactating pregnant mice (Smith \& Biggers, 1968). It also is known that oestrogen administration stimulates uterine adenyl cyclase activity (Rosenfeld \& O'Malley, 1970) and increases the uterine levels of cyclic AMP (Szego \& Davis, 1967). Furthermore, oestrogen activates 'delayed' mouse blastocysts (McLaren, 1971) by rapidly increasing the synthesis of RNA and protein (Weitlauf \& Greenwald, 1968; Holmes \& Dickson, 1975). Apparently, oestrogen is functioning in the uterine target tissue through the first and second messenger system referred to by Robison, Butcher \& Sutherland (1968) in which cyclic AMP is the second messenger.

If oestrogen does act through adenyl cyclase and cyclic AMP (cAMP), it should be possible to administer cAMP and achieve results similar to those following oestrogen administration. The oestrogen-induced implantation of 'delayed' blastocysts represents an interesting system in which to test this possibility.

Albino female mice of the NMRI strain were ovariectomized on Day 3 of gestation, a vaginal plug having been found on Day 1, and were treated subcutaneously with $0.5 \mathrm{mg}$ medroxyprogesterone acetate (Depo Provera: Upjohn) to produce experimental 'delay' (Dickson, 1969). An identical injection was repeated every 5 days. On Day 8 at laparotomy, $10 \mu 1$ of a sterile buffered saline solution of adenosine $3^{\prime}: 5^{\prime}$-cyclic monophosphate (Sigma Chemical

* Present address: Faculty of Medicine, University of Calgary, Galgary, Alberta, Canada.

† Present address: Department of Obstetrics and Gynaecology, University Hospital, S-750 14 Uppsala, Sweden. 
Co.) at $\mathrm{pH} 7.4$ was instilled into the lumen of each uterine horn, the cervix having been ligated to prevent leakage. Control mice received only instillations of saline vehicle. Cyclic AMP solutions were administered in various concentrations as shown in Table 1 and the mice were killed on Day 14. At autopsy, the uterine horns were observed in situ for the presence and position of implantation sites. If no sites were present, the uterine horn was carefully excised and flushed with $2.5 \%$ glutaraldehyde in $0.1 \mathrm{M}$-Sorensen's phosphate buffer at $\mathrm{pH} 7 \cdot 4$ to collect blastocysts.

Mice were killed on Day 32 or Day 48 to determine whether live births were possible after induction of implantation with cAMP. A further group of mice (controls) received $10 \mu 1$ propylene glycol in each uterine horn at laparotomy on Day 8. Samples of the implantation sites induced with cAMP were embedded in methacrylate, sectioned and stained for light microscopy.

Table 1. Implantations induced by cyclic AMP in mice

\begin{tabular}{clccccc}
\hline Group & $\begin{array}{c}\text { Solution } \\
\text { instilled in } \\
\text { uterine horns }\end{array}$ & $\begin{array}{c}\text { No. of } \\
\text { mice }\end{array}$ & $\begin{array}{c}\text { Day } \\
\text { of } \\
\text { autopsy }\end{array}$ & $\begin{array}{c}\text { No. of } \\
\text { blastoysts } \\
\text { collected }\end{array}$ & $\begin{array}{c}\text { No. of } \\
\text { implantation } \\
\text { sites present }\end{array}$ & $\begin{array}{c}\text { No. of mice } \\
\text { with implanta- } \\
\text { tion sites }\end{array}$ \\
\hline 1 & 1 mM-cAMP & 6 & 14 & 15 & 5 & 1 \\
& Saline (control) & 2 & 14 & 7 & 0 & 0 \\
2 & 2 mM-cAMP & 6 & 14 & 1 & 12 & 4 \\
& Saline (control) & 2 & 14 & 6 & 0 & 0 \\
3 & 4 mM-cAMP & 7 & 14 & 4 & 10 & 5 \\
4 & Saline (control) & 4 & 14 & 5 & 0 & 0 \\
& 8 mM-cAMP & 13 & 14 & 19 & 21 & 10 \\
5 & Saline (control) & 4 & 14 & 6 & 0 & 0 \\
6 & 16 mM-cAMP & 5 & 14 & 9 & 1 & 1 \\
& Saline (control) & 3 & 14 & 0 & 0 & 0 \\
7 & 8 mM-cAMP & 6 & 32 & - & 16 & 2 \\
& Saline (control) & 3 & 32 & - & 0 & 0 \\
8 & 8 mM-cAMP & 6 & 48 & - & 9 & 3 \\
& Saline (control) & 3 & 48 & - & 0 & 0 \\
& Propylene glycol & 6 & 14 & 0 & 51 & 6 \\
& Saline (control) & 4 & 14 & 7 & 8 & 4 \\
\hline
\end{tabular}

The results are shown in Table 1. From the first five groups of Table 1, it can be seen that cAMP effectively induced mouse blastocysts in 'delay' to implant. Many implantation sites were recorded in the cAMP-treated experimental mice, whereas none were observed in the control mice injected with saline. The 8 mM-solution of cAMP seemed to be the most effective, although the numbers of mice were too low for reasonable statistical significance. The 8 mm-solution was used again in an attempt to get live births (Groups 6 and 7 of Table 1) and the mice were killed on Days 32 and 48. No live births were recorded and no blastocysts were collected, but implantation sites were present and apparently regressing. The mice killed on Day 48 exhibited fewer, more necrotic implantation sites than those killed on Day 32, probably due to the more advanced stage of resorption.

In another control experiment (Group 8 of Table 1), propylene glycol 
had a clear implantation-inducing effect. In the uteri of these mice, the largest implantation sites were situated most proximal to the cervix where the needle passed through the uterine wall for instillation of the propylene glycol. This oil was used as a control because of its former use as an injectable steroid solvent. It may be exhibiting a specific reactivity in this system or only a non-specific chronic irritant effect. Marston, Kelly \& Eckstein (1971) showed that arachis oil in the uterine lumen of the rhesus monkey would induce a deciduomal reaction. These workers did not, however, investigate the effects of arachis oil on the blastocyst or its implantation. The present results provided no other indications of the mechanism of action of the propylene glycol.

The results further indicate that the implantation of 'delayed' mouse blastocysts, normally induced by oestrogen, can also be induced by cAMP, the second messenger for oestrogen. The fact that no live births were recorded, however, raises further questions: was the stimulus complete enough for normal blastocyst implantation, was the stimulus long enough to maintain a normal implantation and was the blastocyst stimulated in the usual way as with oestrogen-induced implantation? The latter question has been investigated further by scanning electron microscopy (Holmes \& Bergström, 1975). Nevertheless, the present evidence along with that of Szego \& Davis (1967), Rosenfeld \& O'Malley (1970) and Mohla \& Prasad (1970) positively implicates cAMP in the implantation process and yet it is still impossible to say whether either the oestrogen or the cAMP acts directly on the blastocyst.

Ryan \& Coronel (1969) noted in their work that daily intraperitoneal injections of $5 \mathrm{mg}$ cAMP had a contraceptive effect and blocked the occurrence of pregnancy in normal female mice. A histological survey (Pearce \& McClurg, 1971) of the adrenals and reproductive organs after intraperitoneal cAMP elucidated changes in the ovaries, uterus and vagina indicative of a diversity of hormonal effects. The intraluminal instillation of cAMP gave a more local effect, as in the present results, and although pregnancy was not blocked it was not maintained to term.

This research was supported by the Medical Research Council of Canada, and by Grant 12X-80 from the Swedish Medical Research Council. Dr Ove Nilsson, Professor and Chairman of the Department of Human Anatomy, Biomedical Centre, Uppsala, Sweden, generously provided the laboratory facilities for investigation. The authors also are indebted to Ms Barbro Pettersson for her skilled technical assistance and to Ms Bibi Karlsson for preparation of the manuscript.

\section{REFERENCES}

Dickson, A. D. (1969) Effectiveness of 6 $\alpha$-methyl-17-acetoxyprogesterone in combination with oestradiol benzoate, in inducing delayed implantation in the mouse. F. Reprod. Fert. 18, 227-233.

Holmes, P. V. \& Bergström, S. (1975) Cyclic AMP-induced changes in the surface morphology of diapausing blastocysts and the effects of implantation. Am. F. Obstet. Gynec. (in press).

Holmes, P. V. \& Dickson, A. D. (1975) Temporal and spatial aspects of oestrogen-induced RNA, protein and DNA synthesis in delayed-implantation mouse blastocysts. $\mathcal{J}$. Anat. (in press).

Marston, J. H., Kelly, W. A. \& Eckstein, P. (1971) Deciduomal reaction induced in rhesus monkeys by tubal injection of arachis oil and by the presence of an intrauterine device. F. Reprod. Fert. $25,451-454$. 
MaLaren, A. (1971) Blastocysts in the mouse uterus: the effect of ovariectomy, progesterone and oestrogen. F. Endocr. 50, 515-526.

Mohla, S. \& Prasad, M. R. N. (1970) Stimulation of RNA synthesis in the blastocyst and uterus of the rat by adenosine $3^{\prime}, 5^{\prime}$-monophosphate (cyclic AMP). F. Reprod. Fert. 23, 327-329.

Pearce, W. H. \& McClurg, J. (1971) The mode of action of cyclic AMP as a contraceptive. $A m$. 7. Obstet. Gynec. 109, 724-731.

Robison, G. A., Butcher, R. W. \& Sutherland, E. W. (1968) Cyclic AMP. A. Rev. Biochem. 37, 149-174.

Rosenfeld, M. G. \& O'Malley, B. W. (1970) Steroid hormones: effects on adenyl cyclase activity and adenosine $3^{\prime}, 5^{\prime}$-monophosphate in target tissue. Science, N.Y. 168, 253-255.

Ryan, W. L. \& Coronel, D. M. (1969) Adenosine 3',5'-monophosphate as an inhibitor of ovulation and reproduction. Am. 7. Obstet. Gynec. 105, 121-126.

Smith, D. M. \& Biggers, J. D. (1968) The oestrogen requirement for implantation and the effect of its dose on the implantation response in the mouse. F. Endocr. 41, 1-9.

Szego, G. M. \& Davis, S. (1967) Adenosine 3',5'-monophosphate in rat uterus: acute elevation by oestrogen. Proc. natn. Acad. Sci. U.S.A. 58, 1711-1718.

Weitlauf, H. M. \& Greenwald, G. S. (1968) Influence of oestrogen and progesterone on the incorporation of $\mathrm{S}^{35}$-methionine by blastocysts in ovariectomized mice. J. exp. Zool. 169, 463-470. 